\title{
DEVELOPMENT OF FEMALE REPRODUCTION STRUCTURES AND APOMIXIS IN SOME CMS LINES OF SUNFLOWER
}

\author{
Voronova, O.N. ${ }^{*}$
}

Komarov Botanical Institute of RAS, Department of Embryology and reproductive biology, Professor Popov str., 2, Saint-Petersburg, 197376, Russia

Received: April 15, 2013

Accepted: June 10, 2013

\section{SUMMARY}

Under natural conditions, only cross-pollination is typical for sunflower. The apomixis phenomenon was hardly observed in genre Helianthus L. Development of embryo sac at sunflower goes according to Polygonum-type, embryo formation goes according to Asterad-type (Senecio-variation).

On plants of $\mathrm{cms}$-lines a series of experiments on interspecific hybridization was carried out. As a result a number of anomalies in development of female reproductive system were investigated, including such apomixis phenomena as an apospory and integumentary embryony.

In some ovule was noted total absence of embryo sac. All ovule structures were normally formed, but on the place of embryo sac some small and 1-3 large cells were found.

Lack of the main embryo sac and formation of additional aposporous embryo sacs could be observed at the same time in the same ovule.

\section{Key words: apospory, cms, Helianthus, integumentary embryony, interspe- cies hybridization}

\section{INTRODUCTION}

Cytoplasmic male sterile ( $\mathrm{cms}$ ) lines are widely used in sunflower breeding, because they allow breeders to avoid the strenuous process of manual castration of flower in order to create the sunflower genetic variety by hybridization method. Nevertheless, the $\mathrm{cms}$ plants have not been studied in depth. In the case of $\mathrm{cms}$ lines male reproductive sphere was the main object of many studies (Horner, 1977; Simonenko et al., 1978; Balk et al., 2001, etc.), while only in the recent years have researchers begun to study female reproductive sphere of cms lines using cytoembryological analysis (Voronova, 2006, 2008a, 2010; Voronova et al., 2007; Gotelli et al., 2008). The majority of earlier studies of cultivated sunflowers were

* Corresponding author: Phone/Fax: +7(812) 346-44-41; e-mail: o_voronova@list.ru 
carried out on its cultivars (Ustinova, 1955, 1964, 1970; Dzyubenko, 1959; Newcomb, 1973a, b; Toderich, 1988; Yan et al., 1991, etc.).

When plants of cms-lines are taken into account, a series of experiments on interspecific hybridization with the subsequent cyto-embryological research of the process of pollination and fertilization have been carried out. As a result, a number of anomalies in the development of female reproductive system were observed, including phenomena such as an apospory and integumentary embryony (Voronova, 2006-2010; Voronova et al., 2007).

In this article we combined some of our earlier data with the latest results that provide more complex view about first stages of the development of female reproductive structures.

\section{MATERIALS AND METHODS}

The lines of sunflower genus Helianthus annuus L. used for this research were presented in two options: lines with cytoplasmic male sterility (cms) (VIR 114 A, VIR 116 A, VIR 151 A) and their fertile pairs (VIR 114 B, VIR 116 B).

There were four options of experiments carried out:

1. control: sterile forms (A) pollinated by fresh pollen of their fertile pairs (B);

2. heads of $\mathrm{cms}$ plants isolated and not pollinated;

3. the head of the VIR 116 sterile form A pollinated by the pollen of the VIR 116 fertile form $\mathrm{B}$, but the pollen was collected three days prior to pollination and was stored in the refrigerator at the temperature $0-4^{\circ} \mathrm{C}$;

4. heads of $\mathrm{cms}$ plants isolated and pollinated by the pollen of different perennial wild species of Helianthus from VIR collection (Table 1).

The material for cito-embryological investigations was fixed in time, beginning from 1 hour till 9 days after pollination.

The material at different stages of ovule development in plants belonging to Peredovic (standard) cultivar was collected and stored as well.

Separate tubular flowers were taken by pincers from a head and stored in FAA solution (formalin, 70\% ethanol, acetic acid in the ratio 70:100:7). For the accelerated analysis of the material the method of the total clearance of ovule by methylbenzoate was used (Crane, 2001); constant preparations for light microscopy were made according to a routine technique with some changes (Zhinkina et al., 2000; Voronova, 2008b).

Plants were grown in Krasnodar region on fields of the Kuban Experimental Station of N.I. Vavilov Research Institute of Plant Industry.

\section{RESULTS AND DISCUSSIONS}

Research showed that the ovule development and embryo sac formation at the lines VIR 114, VIR 116, VIR 151 and Peredovic happen in a similar way. 
Table 1: Anomalies in ovule development after pollination of $\mathrm{cms}$ lines of cultivars (VIR 114, VIR 116 and VIR151) by wild perennial sunflower

\begin{tabular}{lccc}
\hline Pollination combination & $\begin{array}{c}\text { Ovules which have } \\
\text { been investigated }\end{array}$ & $\begin{array}{c}\text { Ovules without } \\
\text { any embryo sac }\end{array}$ & $\begin{array}{c}\text { Ovules with apospo- } \\
\text { rous embryo sac }\end{array}$ \\
\cline { 2 - 4 } in total & in \% to total & in \% to total \\
\hline VIR $114 \times$ H. ciliaris & 55 & 2.9 & 51.4 \\
VIR $116 \times$ H. nuttalli & 43 & 0 & 14.5 \\
VIR $116 \times$ H. occidentalis & 85 & 20.9 & 14.0 \\
VIR $114 \times$ H. occidentalis & 69 & 1.2 & 11.8 \\
VIR $114 \times$ H. giganteus & 35 & 0 & 10.0 \\
VIR $114 \times$ H. nuttalli & 32 & 34.3 & 8.6 \\
VIR 116 A $\times$ VIR 116 B (pollen & & 0 & 6.7 \\
were stored at t 0-4 ${ }^{\circ} \mathrm{C}$ for 3 days) & 35 & & \\
VIR $\times$ H. divaricatus & 89 & 14.3 & 5.7 \\
VIR $114 \times$ H. hirsutus & 30 & 16.9 & 4.5 \\
VIR $151 \times$ H. occidentalis & 45 & 0 & 3.3 \\
VIR $116 \times$ H. giganteus & 119 & 0 & 2.2 \\
VIR $114 \times$ VIR 114 B & 49 & 3.4 & 1.7 \\
VIR $116 \times$ VIR 116 B & 48 & 0 & 0 \\
VIR $116 \times$ H. maximiliani & 46 & 0 & 0 \\
VIR $116 \times$ H. ciliaris & 45 & 0 & 0 \\
VIR $116 \times$ H. decapetalus & 44 & 0 & 0 \\
VIR $116 \times$ H. mollis & 40 & 0 & 0 \\
VIR $116 \times$ H. strumosus & & 0 & 0 \\
\hline
\end{tabular}

Ovule is created in the base of ovary, about 7-10 before flowering. The ovule primordium is formed by periclinal divisions of cell in the subepidermal placental layer (Figure 1; 1, 2).

The majority of sunflower investigators have suggested that usually 1-2 archesporial cells are formed in subepidermal layer of ovule primordium and then they develop into megasporocyte directly without any mitotic divisions (Ustinova, 1964; Dzyubenko, 1959; Newcomb, 1973a; Toderich, 1988, etc.). But we have noticed that in the ovule primordium several (usually 1-2) "archesporial like" cells are formed and these cells are divided mitotically to give rise to "archesporial proper" cell, the cell which is located under archesporial cell (basal cell) (Figure 1; 3, 4, 5). The basal cell survives for a long time and forms a transition from archesporial cell to hypostasis. To avoid confusion we propose the term "initial cell" to be used before and "archesporial cell" only after mitotical division.

Archesporial cell is elongated and gives rise to the megaspore mother cell (Figure $2 ; 2$ ). The meiotic divisions produce a linear tetrad of haploid megaspores and from one chalazal megaspore a Polygonum-type embryo sac is formed (Figure 2; 3, 4). 

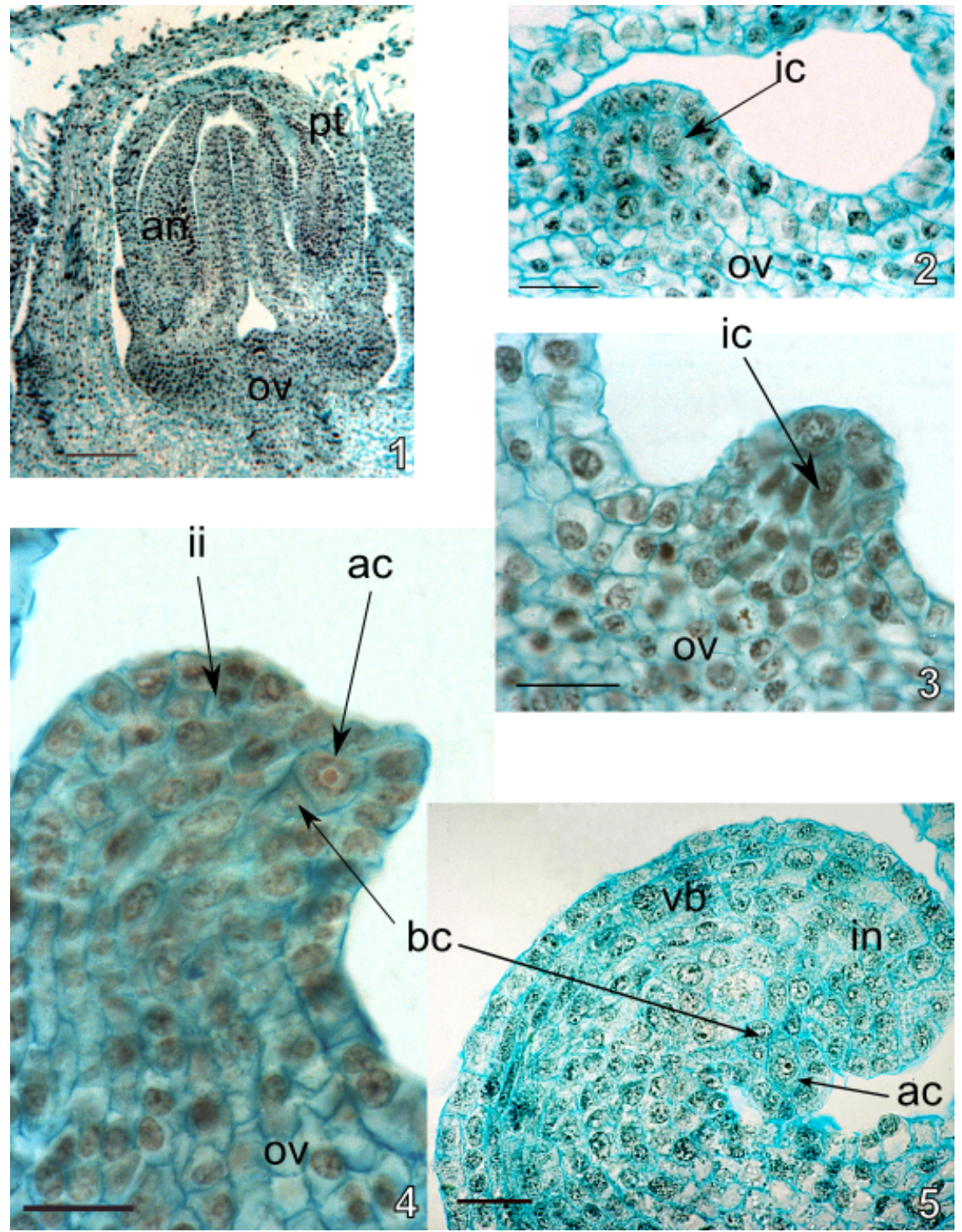

Figure 1: First stages of ovule development in sunflower (1-4 - line VIR 114; 5 - cv. Peredovik). 1 - tubular flower on the stage of ovule primordium initiation,

2 - the ovule primordium with initial cell in subepidermal layer,

3 - the initial cell elongates and starts mitotic division,

4 - the initial cell dived into archesporial cell and basal cell, integument initiates in epidermal layer of ovule, the ovule starts being curved,

5 - the archesporial cell elongates, the integument actively develops, the vascular band initiates in ovule.

ac-archesporial cell, an - anther, bc-basal cell, ic - initial cell, ii - initial of integument, in - integument, ov-ovary, pt - petal, vb-vascular bands.

Scale bars: $1-150 \mu \mathrm{m}, 2-5-30 \mu \mathrm{m}$. 

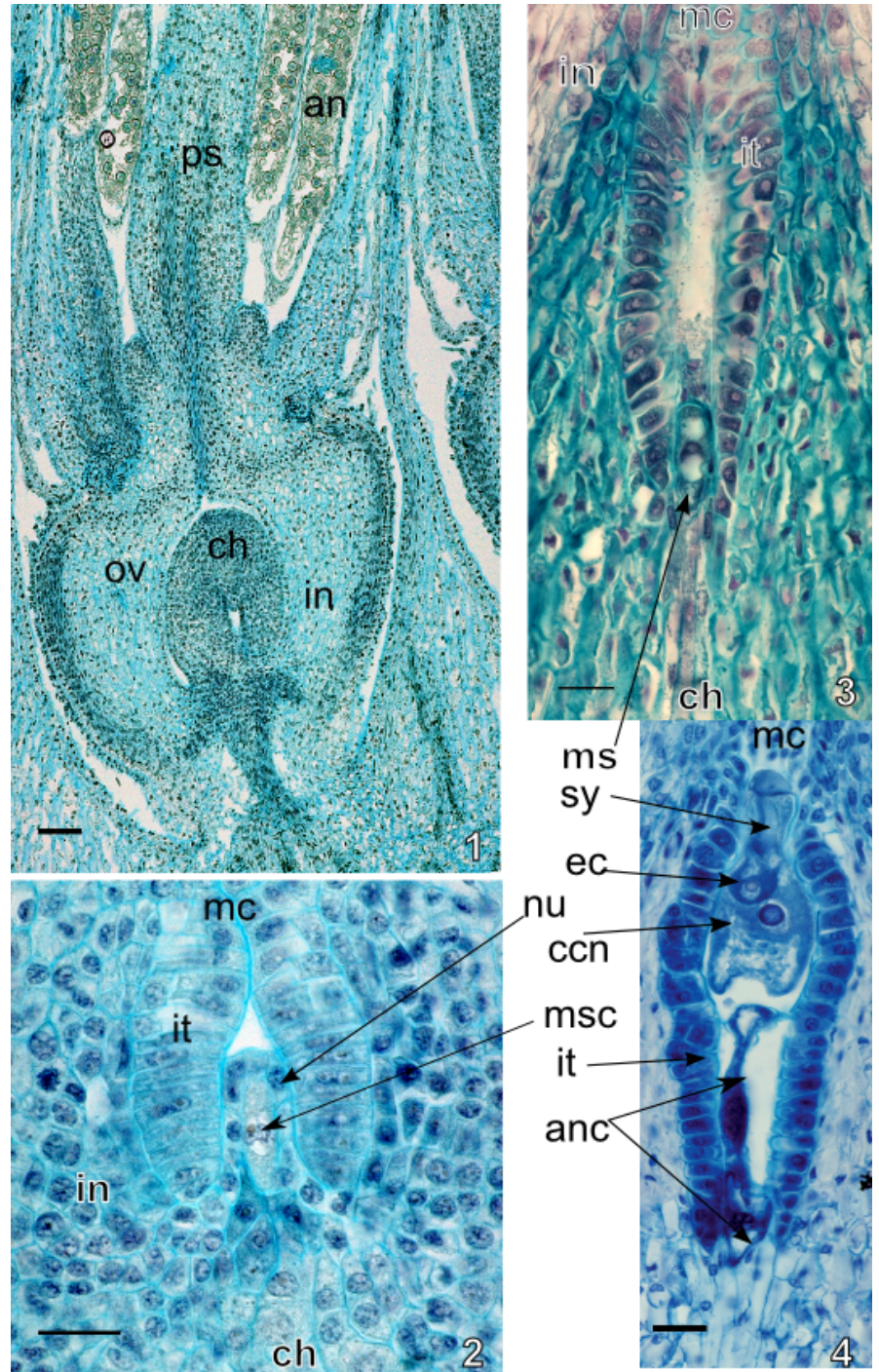

Figure 2: Embryo sac formation in sunflower (1, 2-cv. Peredovik, 3, 4-line VIR 116).

1 - tubular flower on the stage of megasporocyte formation, the ovule curves in anatropous position,

2 - megasporocyte before meiosis, integumentary tapetum forms from epidermal layer of integument around megasporocyte,

3 - ovule with chalazal megaspore, three micropilar megaspore degenerated, walls of integumentary tapetum cell are thickened,

4 - mature embryo sac with synergids, egg cell, two antipodal cells and central cell with big secondary nucleus.

anc-antipodal cell, an - anther, ccn - central cell nucleus, ch - chalaza, ec-egg cell, in - integument, it - integumentary tapetum, mc-micropile, ms - microspore, mscmicrosporocyte, nu-nucellus, ov-ovary, ps - pistil.

Scale bars: $1-150 \mu \mathrm{m}, 2-4-30 \mu \mathrm{m}$. 
Ovule shows a differentiation by zones, which is particularly visible in the central part (Figure $3 ; 1$ ). The cells of the outer zones are elongated with a thin cell wall, whereas, the ones of the inner zone have a thick cell wall which is intensively coloured be alkaline blue (Figure $3 ; 3,4$ ). The vascular bundle passes through chalaza and penetrates integument, almost reaching the micropyle, as in some other Asteraceae species (Musial et al., 2012).

Nucellus early degenerates and remains in the form of a thin film between embryo sac and integument (Figure 2; 2, 3). Internal epidermal cells of integument are differentiated in integumentary tapetum, which is usually single-layered, but can become 2 - 3 - layered at late stages of ovule development. Integumentary tapetum cells are small, flattened, a table-like form, dark-colored, with one or two nuclei. During the development of integumentary tapetum cells its walls are hardly thickened. Later, the integumentary tapetum forms derivates around a mature embryo sac (Figure 2; 2, 3, 4; Figure 3; 2, 4).

Embryo sac is completely created by the time pollination takes place. Mature embryo sac consists of a three-cellular egg apparatus, the central cell with big fusion nucleus and antipodal cells (Figure 2; 4). Egg apparatus consist of three cells in a pear-shaped form - two synergids and the egg. Egg cell nucleus is disposed in the apical part of cell; it is rather big with obvious nucleolus. The synergid nuclei are disposed in the center of cells, morphologically they are hardly distinguishable. There is filiform apparatus with hamiform evagination in the basal part of synergids. The bulk of cytoplasm of the central cell is located near the egg apparatus and thin bundles between large vacuoles. The central cell nucleus is quite large and it is located near the apical end of the egg cell. Antipodes settle down linearly. Antipodal cells are strongly vacuolated, contain large, apparently polyploidy nuclei. Usually there are only two antipodes in a mature embryo sac. Antipodal cell that adjoined the central cell is usually larger underlying and can increase 2-3 times in its size. The remains of the third antipodes in the chalazal end of embryo sac are sometimes observed. The antipodal complex as a whole takes up a half of the general linear size of an embryo sac.

The ovule of the plants pollinated by the pollen earlier influenced by low positive temperatures (option 3), and the pollen of perennial wild species (option 4) revealed the existence of additional embryo sacs (Figure 3; 1,2). They were found at different times after pollination (from two hours to nine days) and in different combinations of pollinations (Table 1).

Additional embryo sac, as a rule, had the wrong form, rather rounded oval, shorter at length, than the main; there is no integumentary tapetum round it. It is located behind the main embryo sac or a little sideways, but, as a rule, does not adjoin it. In the case when not one, but several additional embryo sac are formed, they could settle down without any order, even perpendicular in relation to a longitudinal axis of the main embryo sac. 


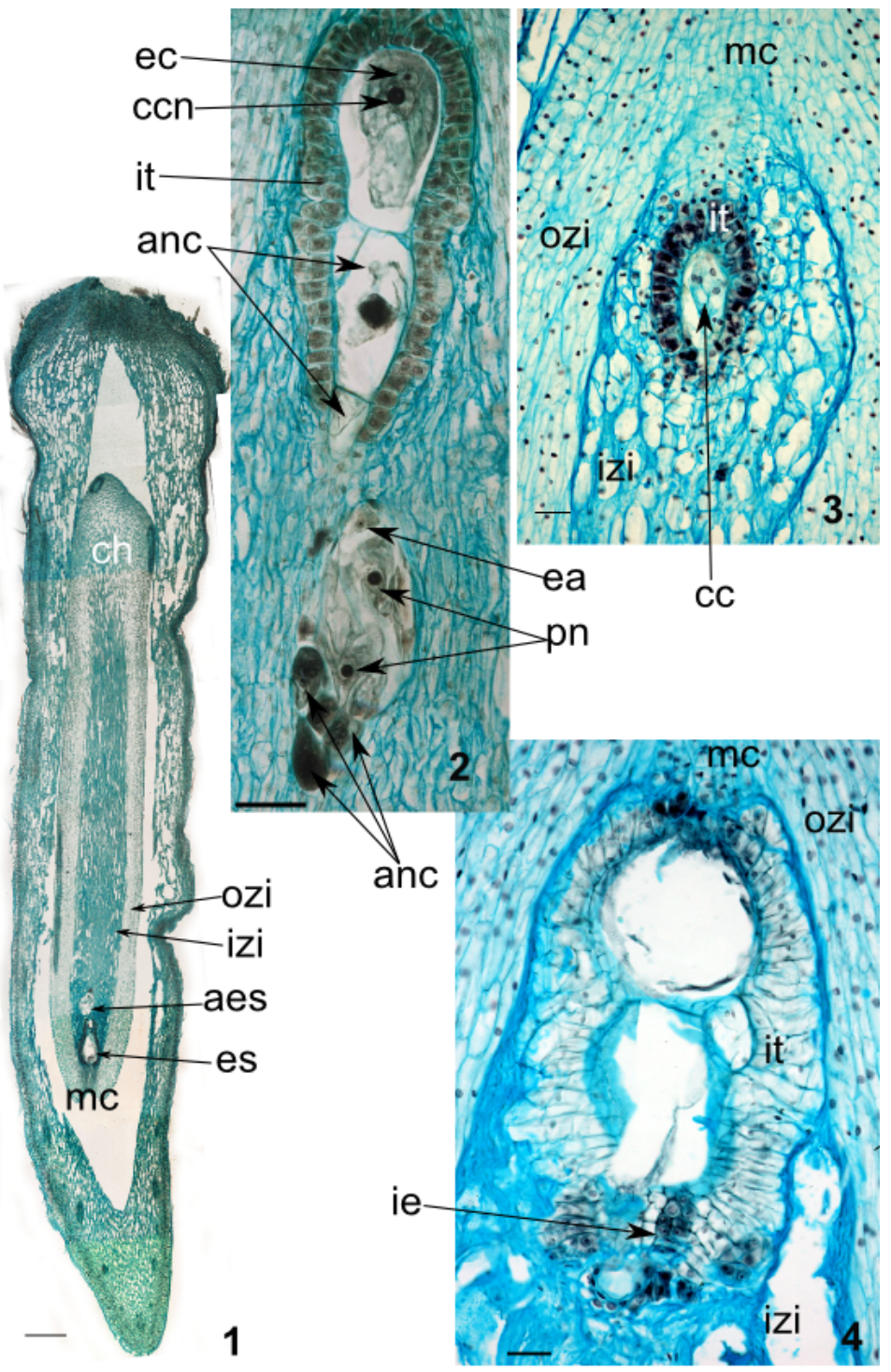

Figure 3: Embryo sac formation in sunflower (1 - 4 - line VIR 116).

1 - ovary on the stage of mature embryo with aposporous embryo sac,

2 - mature embryo sac and aposporous embryo sac with egg apparatus, antipodal cells and two polar nuclei,

3 - ovule with a cell complex instead of a embryo sac,

4 - ovule with integumentary embryo.

aes - aposporous embryo sac, anc-antipodal cell, ccn-central cell nucleus,

ch - chalaza, ec-egg cell, es - embryo sac, in - integument, it - integumentary tape-

tum, izi - inner zone of integument, mc-micropile, ms - microspore, msc-microsporocyte, ozi-outer zone of integument, ov-ovary, pn-polar nuclei.

Scale bars: $1-300 \mu \mathrm{m}, 2-4-30 \mu \mathrm{m}$. 
Additional embryo sac included the same elements, as the main one: the egg cell, the synergids, the central cell with polar nuclei or secondary nucleus and antipodes. All elements of an additional embryo sac were similar to those of the main, but different in sizes and the level of differentiation. There could be more than three antipodal cells, the most frequent being roundish dark-coloured cells (Figure $3 ; 2$ ).

The asynchrony in development of the main and additional embryo sacs was noted. Additional embryo sacs, as a rule, had a delayed development.

The absence of integumentary tapetum around the additional embryo sac, playing a role peculiarly known as «a rigid design», apparently resulted in certain distinctions in shape, of both the embryo sac itself, and some of its elements.

The main embryo sac in all cases had a normal structure, typical of sunflower.

We suggested that aposporous should be the additional embryo sac. The relative position of the additional and main embryo sacs goes in its favour. Besides, at earlier stages of development groups of big microspore-like cells were found around chalazal forming the end of main embryo sacs (Voronova et al., 2007).

Young embryos were found and further high-grade seeds were formed in control plants (option 1 and cv. Peredovic). In plants without pollination (option 2) and those pollinated by wild types and by pollen after cold treatment (options 3 and 4) gradual degeneration of both types of embryo sacs was observed and, as a rule, puny seeds without an embryo were formed.

In a separate ovule of some cms lines (VIR 114, VIR 116) a surprising phenomenon was noted - the total absence of embryo sac (Figure 3 ; 3). In earlier literature the total absence of the embryo sac was noted only for the tetraploid form of sunflower, but the author was talking about the underdevelopment of the ovule in general (Efremov, 1967). In our investigation, all ovule structures were normally formed, phases of their development and a relative positioning of elements corresponded to the stage of flower development. In the place of the embryo sac, in a cavity surrounded by integumentary tapetum, some small and 1 - 3 large cells, with light, strongly vacuolated cytoplasm, and small nuclei were found. Possibly, those cells are original derivatives of nucellus (Voronova, 2006, 2008a). In usual conditions, nucellus cells appear in a squeezed form, developing that way megasporocyte and by the time of the formation of an embryo sac they completely degenerate. It is possible to assume that owing to the lack of an embryo sac, the transport of nutrients in this zone remains untouched and, in the absence of an effect from outside megasporocyte, nucellus cells are capable of surviving for a long time.

The lack of the main embryo sac and formation of additional embryo sacs could be observed at the same time in the same ovule (Table 1). In case of seed formation from a similar ovule, the embryo in them could be formed only by the means of apomixes. 
In some ovule of cms line VIR 116 the formation of integumentary embryo was observed (Figure 3; 4). Parent plants were pollinated by $\mathrm{H}$. occidentalis pollen. Though pollination was carried out, fertilization wasn't observed even 7 - 9 days later after pollination. In a normal case at this time the embryo and endosperm in the ovule would be observed, but in some plants of $c m s$ line VIR 116 the embryo sac still existed at this stage, getting an 8-shaped form. As a rule, it was still possible to discern components - egg apparatus, central cell with secondary nucleus and antipodes. Sometimes egg cell was significantly bigger, and synergids, on the contrary, were compressed and darkened. Egg nucleus could become bigger than secondary nucleus of the central cell. Cytoplasm of the central cell occupied the wall with a huge vacuole in the centre; secondary nucleus was located near the egg cell.

Integumentary tapetum became multilayered and folded with transparent cells and small and hardly visible nuclei. An integumentary tissue near the chalazal pole of the embryo sac was destroyed and the cells were lysed, followed by the formation of cavities.

Integumentary embryos were located in the chalazal region of the integumentary tapetum; their apical poles were turned to the micropyle. The embryos consisted of 1 - 2 suspensor cells and 7 - 8 embryonic cells, which were dark-colored and had large nuclei with clear nucleoli. In their structure they corresponded to Asterad-type embryos (Senecio -variation).

At earlier stages, we observed some peculiar cell complex within the tissue of the integumentary tapetum. This complex consisted of small cells with dense cytoplasm and a large active nucleus; these cells were clearly distinguished among other integumentary tapetum cells, which were transparent and had hardly visible nuclei. Some part of cells in that complex was grouped in 2 - 4 cells and looked like two- or four-celled embryos. Apparently, this stage can be considered as intermediate in formation of integumentary embryos.

In control plants (pollination of the VIR 116 A line with the pollen of the fertile analogue of the VIR $116 \mathrm{~B}$ and pollination of the cv. Peredovic), we observed formed embryos and endosperm on the $7^{\text {th }}-9^{\text {th }}$ days after pollination; subsequently the full-values seeds were set. Unfortunately, we did not observe the formation of full-values seed after pollination of the $\mathrm{cms}$ line with the pollen of wild sunflower species: the seeds, formed in the head, did not contain embryos. It is known that interspecific hybridization in sunflower is realizable, but the number of seeds routinely formed is very insignificant: 1-10 per head (Gavrilova et al., 2003).

\section{CONCLUSION}

As a result of this research three types of deviations in the cms reproductive system of lines were found: lack of a embryo sac, apospory and integumentary embryony. The latter two represent different forms of apomixis. 
It was noted that apomixes phenomenon is connected with hybridization in different systematic groups (Carman, 1995). Cms lines obtained a sterile cytoplasm from wild sunflower species (Leclerq, 1969) and, therefore, have an interspecies hybridization in their pedigrees (Voronova et al., 2007). Possibly, that is why their reproductive system is less stable than the one in cultivated species and the alternative ways of development (apospory and integumentary embryony), rare for the cultivated sunflower but typical of other representatives of the Asteraceae family (Noyes, 2007), start to work under stress conditions (pollination with an alien pollen, delay or the full absence of the fertilization).

Based on the earlier published data (Molchan, 1973; Petrov, 1988), we can suppose that the pollination of cultivated sunflower with the pollen of wild Helianthus species, as well as the absence of normal fertilization, can stimulate the alternative way of development of reproductive system and the appearance of different anomalies in morphogenesis of ovule structures.

In the course of sunflower selection work interspecific hybridization was repeatedly used, while the type of pollination changed: at the first stage there was a search for self-fertile forms, then among them sterile lines were allocated and supported by self-pollination. Finally, in order to obtain industrial heterosis hybrids, the cms lines were again cross-pollinated. However, the balance existing in the reproductive system of cultivars appeared lost in lines and hybrids.

Integumentary embryony, as one of apomixes forms, represented indubitable theoretical and practical interest because it implied embryo formation from cells of somatic tissue of ovule. By origin integumentary embryos represent clones of a parent organism; their formation can result in genetic heterogeneity (to existence both matroclinal, and the mixed heredity) even within progeny of one plant (Batygina et al., 2007). For this reason the possibility of integumentary embryos formation in cultural sunflower not only represents a theoretical interest, but also allows explaining deviations from expected results of cross-breeding (Lyashchenko, 1940, 1948; Gavrilova et al., 1997; Faure et al., 2002).

It was observed in other objects that the initial cells of integumentary embryos are formed at a certain stage of ovule development, corresponding to the time when the normal embryo should start to develop (Naumova, 2008). In our study, we observed a similar picture: integumentary embryos were developed in empty afterpollination ovules at the stage when the normal embryos should be formed. When the violation took place at an earlier stage, the alternative (aposporic) embryo sacs were formed. Apospory embryo sac and initial cells of integumentary embryo are formed at a fixed stage of ovule development, the first - when formation in question is female gametophyte, the second - when the development a sexual embryo should begin. The type of alternative (additional) structures that will be formed depends on a general stage of the ovule development and on the time that passes after pollination. 
The program of development is performed without any violations or anomalies in amphimicts, whereas in apomicts it occurs with some deviations. However, due to the functioning of the system, providing reliability of reproduction (Batygina, 1994) and due to the activation of alternative ways of morphogenesis, this program finally results in embryo formation.

\title{
ACKNOWLEDGEMENTS
}

\author{
I am grateful to Dr. V. A. Gavrilova (N. I. Vavilov Research Institute of \\ Plant industry) and Dr. V. T. Rozhkova and Dr. T. T. Tolstaja (the Kuban \\ Experimental Station) for their help in the provision of experimental \\ material.
}

This work was supported by the Russian Foundation for Basic Research (project No. 11-04-01466).

\section{REFERENCES}

Balk, J., Leaver, Ch.J., 2001. The PET1-cms mitochondrial mutation in sunflower is associated with premature programmed cell death and cytochrome c release. The Plant Cell 13: 1803-1818.

Batygina, T.B., 1994. Apomixis, agamospermy and vivipary and its role in plant reproduction system. In: Apomixis in plant: the problem stage and perspective of investigation [Apomiksis u rastenij: sostojanie problemy i perspektivy issledovanij], Saratov, pp. 1618. (In Russian)

Batygina, T.B., Vinogradova, G.Ju., 2007. Phenomenon of polyembryony. Genetic heterogeneity of seeds, Ontogenez 38(3): 166-191. [Russ. J. Dev. Biol. (Eng.Transl.): 38(3): 126-151].

Carman, J.G., 1995. Gametophytic angiosperm apomicts and the occurrence of polyspory and polyembryony among their relatives. Apomixis Newsletter 8: 39-53.

Crane, C.F., 2001. Classification of apomictic mechanisms. Appendix: Methods to clear angiosperm ovules. In: Savidan, V., Carman, J.G., Dresselhaus, T. (Eds.), The flowering of apomixes: from mechanisms to genetic engineering, Mexico, pp. 35-43.

Dzyubenko, L.K., 1959. Cytoembryological studies of female generative zone in ovule of the sunflower (Helianthus L.). Ukr. Bot. Zh. 16(3): 8-19. (In Ukraine)

Efremov, A.E., 1967. Morphological and cytoembryological peculiarities of tetraploid sunflower. Genetika 11: 31-36. (In Russian)

Faure, N., Serieys, H., Cazaux, E., Kaan, F., Berville, A., 2002. Partial hybridization in wide crosses between cultivated sunflower and the perennial Helianthus species H.mollis and H.orgyalis. Annals of Botany 39: 31-39.

Gavrilova, V.A, Anisimova, I.N., 2003. Genetics of cultivated plants. The Sunflower [Genetika kul'turnyh rastenij. Podsolnechnik]. VIR, St.-Petersburg, pp.1-209. (In Russian)

Gavrilova, V.A., Tolstaya, T.T., Rozhkova, V.T., 1997. Analysis of interspecific hybrids resulting from crosses between perennial wild Helianthus species and the cultivated sunflower. In: FAO Progress Report 1995-1996, Germany, pp. 75-80.

Gotelli, M.M., Galati, B.G., Medan, D., 2008. Embryology of Helianthus annuus (Asteraceae). Ann. Bot. Fennici 45(2): 81-96.

Horner, Y.T.Jr., 1977. A comparative light- and electron-microscopic study of microsporogenesis in male-fertile and cytoplasmic male-sterile sunflower (Helianthus annuus). American Journal of Botany 64(6): 745-759.

Leclerq, P., 1969. Une sterilite cytoplasmique chez le tournesol. Ann. Amelior. Plant 19: 99-106.

Lyashchenko, I.F., 1940. A case of absence of splitting in sunflower hybrids. Dokl. Akad. Nauk SSSR 27(8): 824-826.

Lyashchenko, I.F., 1948. The phenomenon of maternal heredity in the sunflower. Uchenye zapiski Rostov. Gos. Univ. 12(1): 3-26. 
Molchan, I.M., 1973. Genetic and physiological role of pollen in apomictic plants. In: Problemy apomiksisa $\mathrm{u}$ rastenii i zhivotnykh [Problems of apomixis in plants and animals], Novosibirsk, 1973, pp. 220-228.

Musial, K., Plachno, B.J., Swiatek, P., Marciniuk, J., 2012. Anatomy of ovary and ovule in dandelions (Taraxacum, Asteraceae). Protoplasma Jun 2013, 250(3): 715-722. Doi: 10.1007/s00709-012-0455-x. Epub. Sept. 23, 2012.

Naumova, T.N., 1993. Apomixis in angiospers. In: Nucellar and integumentary embryony, CRC Press, Boca Raton, pp. 1-144.

Naumova, T.N., 2008. Apomixis and amphimixis in flowering plants. Tsitol. Genet. 42(3): 51-63.

Newcomb, W., 1973a. The development of the embryo sac of sunflower Helianthus annuus before fertilization. Can. J. Bot. 51: 863-878.

Newcomb, W., 1973b. The development of the embryo sac of sunflower Helianthus annuus after fertilization. Can. J. Bot. 51: 879-890.

Petrov, D.F., 1988. Apomiksis v prirode i opyte [Apomixis in nature and experiment], Nauka, Novosibirsk, pp.1-211.

Simonenko, V.K., Karpovich, E.V., 1978. Cytological demonstration different types of male sterility in sunflower. Nauchno-Tehnicheskij Bull. Vsesojuz. Gen. Inst. 31: 32-38.

Toderich, K.N., 1988. Sunflower (Helianthus annuus, H. rigidus, etc.) embryology. Cand. Sci. (Biol.) Dissertation, Leningrad, pp. 1-256.

Ustinova, E.N., 1955. The apospory phenomenon in the sunflower. Dokl. Akad. Nauk SSSR 100(6): 1163-1166.

Ustinova E.N., 1964. Variability of female gametophyte in the sunflower (Helianthus annuus L.). Byul. MOIP. Otd. Biol. 69(4): 111-117.

Ustinova, E.N., 1970. Apomixis in the sunflower. In: Apomiksis i selektsiya [Apomixis and Breeding], Nauka, Moscow, pp. 110-116.

Voronova, O., 2006. Abnormalities in the development of generative organs in some $\mathrm{cms}$ sunflower lines. In: Conferința ştiințifică internațională „Invățămăntul superior şi cercetarea - piloni ai societății bazate pe cunoaştere” dedicată jubileului de 60 ani ai Universității de Stat din Moldova (28 September 2006, Chişinău, Moldova). CEP USM, Chişinău, pp. 335-336.

Voronova, O.N., 2008a. Development features of a generative system in some $\mathrm{cms}$ lines of sunflower. Gen. Res. Rast. 6: 76-81.

Voronova, O.N., 2008b. Rapid analysis by clarification and its use in embryology. Bot. Zh. 93(10): 1620-1625.

Voronova, O.N., 2010. Integumentary embryony in cms sunflower line. Ontogenez 41(6): 455460 [Russ. J. Dev. Biol. (Eng.Transl.) 41(6): 394-399].

Voronova, O.N., Gavrilova, V.A., 2007. Apospory in the sunflower. Bot. Zh. 92(10): 1535-1544.

Yan, H., Yang, H.-Y., Jensen, W.A., 1991. Ultrastructure of the developing embryo sac of sunflower (Helianthus annuus) before and after fertilization. Can. J. Bot. 69(1): 191-202.

Zhinkina, N.A., Voronova, O.N., 2000. On staining technique of embryological slides. Bot. Zh. 85: $168-171$.

\title{
DESARROLLO DE LAS ESTRUCTURAS DE REPRODUCCIÓN FEMENINA Y LA APOMIXIS EN ALGUNOS cms LÍNEAS DE GIRASOL
}

\author{
RESUMEN
}

En condiciones naturales, sólo la polinización cruzada es típica para el girasol. El fenómeno apomixis apenas se observó en el género Helianthus L. El desarrollo del saco del embrión en el girasol va según el Polygonum-tipo, la formación del embrión va según el Asterad-tipo (Senecio-variación).

En plantas de líneas del $\mathrm{cms}$ una serie de experimentos en hybridization interespecífico se realizó. Por lo tanto varias anomalías en el desarrollo del sistema reproductivo femenino se investigaron, incluso tales fenómenos apomixis como un apospory e integumentary embryony. 
En algún óvulo se notó ausencia total del saco del embrión. Todas las estructuras del óvulo normalmente se formaban, pero en el lugar del saco del embrión unos pequeños y 1-3 células grandes se encontraron.

La carencia del saco del embrión principal y la formación de sacos del embrión aposporous adicionales se podrían observar al mismo tiempo en el mismo óvulo.

\section{DÉVELOPPEMENT DES STRUCTURES DE REPRODUCTION DES FEMELLES ET APOMIXIE EN QUELQUES LIGNES Cms DU TOURNESOL}

\section{RESUME}

Sous les conditions naturelles, seulement la trans-pollinisation est typique pour le tournesol. Le phénomène apomixis a été à peine observé dans le genre Helianthus L. Le développement de sac d'embryon au tournesol va selon le Polygonum-type, la formation d'embryon va selon l'Asterad-type (Seneciovariation)

Sur les usines de cms une série d'expériences sur l'hybridation interspécifique a été réalisée. Par conséquent un certain nombre d'anomalies dans le développement de système reproducteur femelle ont été enquêtées, en incluant de tels phénomènes apomixis comme un apospory et integumentary embryony.

Dans un ovule a été noté l'absence totale de sac d'embryon. Toutes les structures d'ovule étaient normalement formées, mais sur l'endroit de sac d'embryon certains petits et 1-3 grandes cellules ont été trouvés.

Le manque du sac d'embryon principal et la formation de sacs d'embryon aposporous supplémentaires pourraient être observés en même temps dans le même ovule. 
